\title{
Narcissism and violence: criminological understanding from a homicide case of complete decapitation
}

\author{
Gabriele Roccal, Alessandro Bonsignore ${ }^{2, *}$, Ignazio Grattagliano ${ }^{3}$, Fiorella Caputo ${ }^{2}$, Francesco Ventura ${ }^{2, *}$, \\ Alfredo Verde ${ }^{1}$
}

Abstract: Prompted by a particularly brutal case of homicide, in which the victim was completely decapitated, the authors provide some suggestions for reflection on the theme of narcissistic aggressiveness. Starting from the pathological-forensic analysis of the lesions inflicted, they then examine the role of narcissism from a criminological standpoint, with particular regard to threatened egotism and grandiosity as a trigger of murder.

This point of view could help forensic pathologists to understand the psychological aspects of homicide cases.

Key Words: narcissism, aggressiveness, homicide, decapitation, threatened egotism, forensic pathology, forensic psychiatry.

\section{INTRODUCTION}

Decapitation is an injury rarely encountered in civilian populations and accounts for about $0.1 \%$ of forensic autopsies $[1,2]$.

The reasons for post-mortem decapitation are varied [3], however cutting a body after death may be a manifestation of significant psychiatric illness in the perpetrator and raises significant questions regarding the nature of the death and the mental status of the author [4].

It has been amply reported in the literature that narcissists can become violent when they suffer a threat to the Self $[5,6]$. However, the role of provocation, as opposed to the aggressor's basic personality, has been scantly studied from the criminological standpoint.

In order to better assess the importance of understanding the "sense" in the psychiatric-forensic evaluation of such situations, we present a case of family homicide in which a man killed his uncle, apparently over a dispute concerning a piece of land, but which actually stemmed from a pathological relationship between the two men.

\section{Case history}

The subject has a brother seven years younger than him; he describes their relationship as positive, though not affectionate. His parents are alive: his father, a retired electrician, is an invalid as a result of transverse myelitis; his mother, a housewife, does not suffer from any noteworthy illnesses.

His relationship with his parents is depicted as profoundly ambivalent. His early childhood - until the time his brother was born, he claims - was marked by continual rows between his parents, which culminated, on one occasion, in an act of extreme violence by the father; when the subject was about five years old, his father actually tried to strangle his mother, and was only prevented from doing so by the boy's intervention. He painfully recalls the tension caused by his parents' rows,

1) University of Genova, Section of Criminology, Department of Health Sciences, Genova, Italy

2) University of Genova, Section of Legal and Forensic Medicine, Department of Health Sciences, Genova, Italy

* Corresponding author: University of Genova, Section of Legal and Forensic Medicine, Department of Health Sciences,

Via A. de Toni 12, 16132 Genova, Italy, E-mail: francesco.ventura@unige.it

3) University of Bari, Section of Forensic Psychiatry, Bari, Italy 
which - he claims - even conditioned him negatively against the idea of marriage and fatherhood. The situation seems to have improved with the birth of the subject's brother, though the relationship between the parents remained somewhat tense.

At the beginning of an interview, he describes his parents' attitude towards him as affectionate and caring. As the interview progresses, however, a different picture emerges. The father is depicted as a hard man, who "wanted a macho son" and, for this reason, expected a lot of the boy without ever giving him any gratification. The mother is also described ambivalently - on the one hand, as strict and detached, on the other as overprotective. "She planted a sadomasochistic attitude in me", he claims. $\mathrm{He}$ denies the presence of any psychiatric disorders in previous or current generations of the family. Regarding his own youth, he says that he developed a passion for nature at an early age; as a child, he was a Boy Scout, and now has fond memories of the times spent at summer camps. His love for the outdoors gradually became a part of himself, thanks mainly to his uncle (the murder victim), who instilled this passion in him. Of his uncle, he says, "He was my favorite uncle; he made me feel like a red Indian; we used to live nature". He describes himself as a very imaginative child, who liked to read adventure stories and to dream of living out such experiences.

He says that he did not have any serious illnesses during his youth. However, he states that he had difficulties in the sexual sphere, in that he "always felt inadequate", and immediately ascribes this to a traumatic childhood experience, i.e. hearing his parents engaging in sex.

Regarding his educational background, he reports that he went through elementary school and middle school without any difficulty, after which he attended a Nautical Institute. He chose this latter type of high school with a view to realizing his dreams of adventure. After taking his diploma, however, he went to sea only twice; both experiences were unpleasant, not least owing to the violent death of a seaman during the first voyage. In reality, however, it seems that the subject had come to realize that the life of a seafarer was not for him, especially since it would have kept him away from the woodlands that he loved.

He subsequently enrolled at university, though he did not attend lectures or take any exams. It was in that period that the traumatic death of his "foster brother" occurred. This "brother" was a homosexual and a drug addict man who was found hanged. The subject poignantly recalls this loss, especially because it was apparently inexplicable.

Shortly afterwards, the subject was conscripted for military service, an experience so disagreeable that he spent almost the entire period on sick leave. From the available documentation and from his own account, it emerges that he was suffering from anxious- depressive symptoms. When questioned about his experience, he reports having difficulty in adapting to authority and the rigors of military life. On returning home, he took a professional training course in nursing and was subsequently employed in the Department of Haematology and Oncology at the local hospital, where he worked for several years without problems or difficulties of any kind. He took pride in the appreciation expressed by colleagues and patients alike. "We were the good fighting against the bad; I used to dream of the day when a cure for leukaemia would be discovered", he adds. After attaining financial independence, he sought to fulfil his wish to go and live in the country. He enthusiastically remembers the effort of "fixing up" the house, and the days spent between hospital shifts and building work. His greatest gratification, however, was having that piece of land which he could call his own, where he could live freely and in peace, together with his dogs. From the social point of view, he comes across as reserved and solitary, explaining that he has a "tendency to stay away from other people"; he describes himself as "out of place" and old-fashioned, but does so with pride. He says that he has only ever had one true friend, in his youth, because he has "difficulty in finding people who measure up".

Nevertheless, he managed to make room for socialization - both at work and by frequenting a folk dance company in the evenings. Moreover, from these settings his most important sentimental experiences emerged: two women whom he had first met at work and subsequently met again as widows. With the first of these, "everything was perfect, especially sex", except for the fact that the woman was unwilling to share his rural life. This refusal, together with the fact that he finally felt sexually adequate, seems to have prompted him to betray the woman's trust and to seek other relationships. His relationship with the second woman is described as being of great harmony of character, not least because she was - according to him very willing to accept his life in the country.

Sexuality, however, seems to have remained a problem area, in that it had always been experienced in an unstable and egodystonic manner. Indeed, after his first approaches in adolescence (and an undefined homosexual experience in his youth), he had always harboured feelings of inadequacy.

To return to the professional sphere, after several years in Haematology and Oncology, the subject began to feel overburdened with work, not least on account of staff cuts. He therefore applied for a transfer to another department and was allocated to the Psychiatry Ward, where he remained for about five years. He describes this work as arduous, because "It wasn't easy working with mad people. It was pretty scary at night; you never knew what they might do if they took it into their heads".

Regarding leisure time activities, in addition to the outdoor life and dogs, the subject had a keen interest in firearms and practised at the local rifle range, becoming 
very proficient, he says. Socially, he claims to have been well accepted by the community: "They made me feel important because I livened up the village". Subsequently, however, he became disheartened by what he saw as disrespect for the law on the part of some of the locals, who, in his opinion, were always ready to disregard building and land regulations if it was in their interests to do so. In support of this claim, he quotes several instances of the creation of unauthorized pathways, non-regulation buildings, the illegal dumping of waste materials, and poaching. However, while condemning such practices, which he sees as spoiling the purity of nature, he nevertheless believes that, in the country, people have the right to do what they think fit, without having to answer to anyone; as long as he was not directly affected, he would turn a blind eye.

Things changed, however, when some local people wanted to turn a footpath across his land into a vehicular road, so that they could gather timber from the nearby wood. In order to settle the ensuing dispute, the subject suggested a compromise - erecting a gate and giving the key to the few people who would use the road. The villagers, however, proved uncooperative, frequently leaving the gate open. He would therefore have to go and close it himself, with the added irritation that he no longer felt he was the master of his own property.

It was against this backdrop that the subject first clashed with his uncle, whom he accused of having dumped waste material in the vicinity of his house. When questioned about the matter, he claimed that his uncle had always thought only of himself, never of anyone else; that he was prepared to act disrespectfully, and even illegally, to get what he wanted. He depicts the older man in an intensely ambivalent manner: on the one hand, as a role model, to whom he was grateful for having taught him to love nature; on the other, as a cunning poacher who was always ready to take advantage of other people.

On that occasion, the subject reacted to his uncle's "incivility" by reporting the matter to the Forestry Police, who subsequently intervened. The uncle was furious. After insulting his nephew, he refused to speak to him again. This quarrel had repercussions throughout the whole family, which upset the subject greatly, especially since he deemed the older man's reaction to be unfair and out of proportion. In the meantime, the question of the road seems to have quietened down and, despite the uncle's continued coldness, no further problems of any kind arose in the following years.

A few months before the homicide, however, the dispute concerning the roadway was rekindled when the subject erected fencing to restrict its vehicular use. The local people objected and communicated their discontent not only directly to the subject and his parents, but also to the mayor, who apparently took their side. In response, the subject forged letters signed with false names, in which he reported various infractions previously committed in the village.

Above all, however, putting up the fence reignited the quarrel with his uncle, who frequently used the roadway. On several occasions, the older man had told him to take the fencing down, and, allegedly, had even threatened to shoot him. The tension steadily rose and the subject began to fear that the land to which he was so attached might be expropriated. Moreover, he became aware of the growing hostility towards him in the village, but could not understand why the locals failed to see his point of view.

$\mathrm{He}$ also reports having been the victim of intimidatory acts: screws were driven into the tires of his tractor, fence-posts were moved or knocked down, and one villager even made him a gift of a few bullets. This stress was aggravated, he says, by an assault on his father, perpetrated by another local man on account of the fence, and - especially - by the mysterious death of one of his dogs, which, he believes, was poisoned. This latter act triggered the memory of a time when he had seen his uncle walking his (the subject's) dogs nearby; this had been surprising, as his uncle was no particular animal lover, and aroused the suspicion (which he still harbours) that his uncle had been responsible for the poisoning.

The subject reports that, as the tension grew, he felt the need to protect himself; he took to going around armed, keeping his pistol always loaded, and installed surveillance cameras around the boundaries of his property and close to the dogs' kennels. He also set up a sort of lookout post and even went so far as to patrol his land at night, to check that everything - and especially the fencing - was in order. However, the event that offended him most was a telephone call from the mayor, who allegedly threatened to expropriate the disputed land. This was seen as intolerable intimidation, and the subject decided to seek the advice of a well-known law firm.

This was the scenario in which the murder was set.

The subject remembers waking up early that morning and seeing his uncle's car parked close to the house. According to his reconstruction of the events, he decided to go and speak to him, to settle the question and to ask the older man to use his influence to dissuade the mayor from expropriating the land. He says he took his pistol with him because his uncle, being a hunter, might have been armed. He remembers loading the pistol with two cartridges - one containing a single bullet, the other containing pellets - the same ones that had been delivered to him as a threat. He also remembers having taken his machete, which "was like a part of me".

Having wandered around in the woods for some time, he came across his uncle, who was picking mushrooms. In recounting the events that followed, he is extremely lucid and emotionally involved. He claims to have called out the older man's name twice, without reply, 
and then to have shouted "Uncle", finally catching his attention. He says that his attempts to broach the subject of the roadway were immediately met with insults, to the effect that he was a disgrace and no longer belonged to the family. Then, the older man spat and made a gesture of a backhand slap, after which, he turned on his heel and walked off.

The subject had the sensation of "a dam bursting". The sting of his uncle's words was too painful to bear; he drew his pistol, aimed at the man's head and fired two shots. He remembers how the body dropped to the ground, and how a huge destructive rage welled up in him. Taking his machete, he lunged at the body and began to hack at the neck, desisting only when he felt the ground under the blade.

On his way back home, he thought about what to do; he decided to try to hide the incident, thinking that otherwise his dogs would be left on their own. At home, he changed his clothes and then return to the wood, where he moved the body, placing it in a hollow and covering it with bushes: "that was his grave", he asserts. He says that he put the severed head, the machete and his bloodstained clothing into plastic bags, which he then threw into the communal rubbish bins.

He remembers the interviews with journalists and investigators before being arrested. It was then that

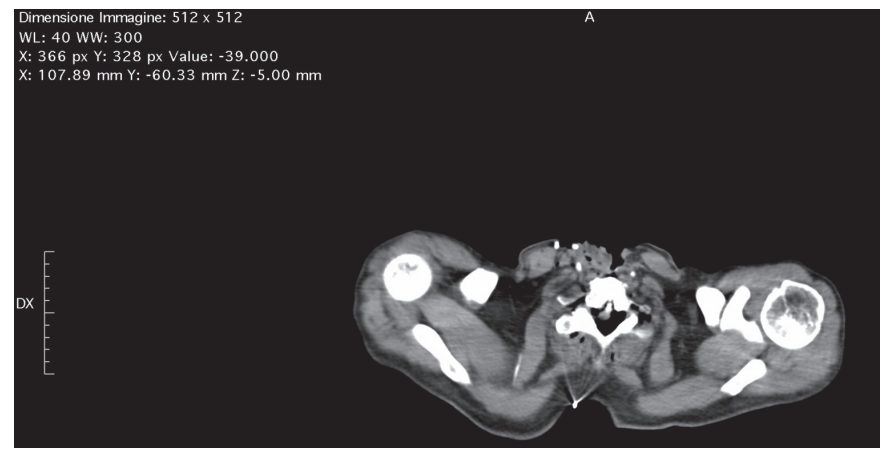

Figure 1. Post-mortem CT Scan: Complete decapitation at C4-C5 and presence of 5 small metallic fragments in the soft tissues between C6 and C7.

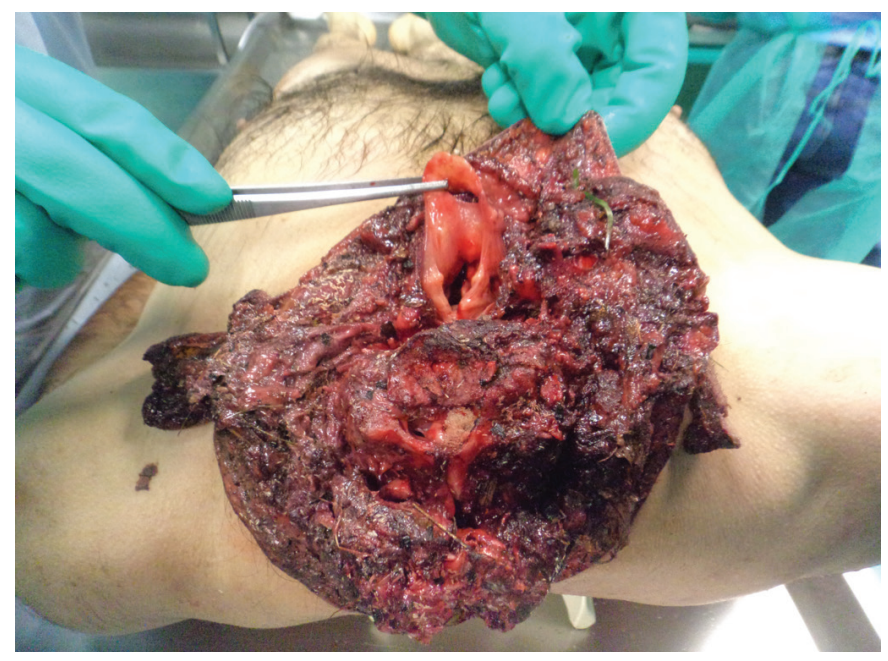

Figure 2. External examination: Degloving neck injury. he decided to confess everything. He is nevertheless at pains to point out that, in the days following the murder, he felt alive and happy, even pleased.

When first taken into custody, he felt ill-at-ease, though now he has adapted well enough. He says that he is sorry about what happened, albeit in a superficial and detached manner.

\section{Pathological-forensic examination}

A decapitated body was found down in a woodland beside a tree. No blood was present in the vicinity. The body, which was subsequently identified as that of a 68-year-old male, underwent forensic autopsy.

Before post-mortem examination, a CT scan was performed; this revealed complete decapitation at C4-C5 and the presence of 5 small metallic fragments in the soft tissues between C6 and C7 (Fig. 1).

On external examination, it was noted that there were at least three different circumferential skin laceration with quite regular edges, exposing the transected supraglottic region and the neck structures (Fig. 2).

Contamination by foliage and soil was observed on the victim's clothes, neck and body.

Sixteen contusions and five entrance wounds, without corresponding exit wounds, were present on the victim's upper back and in the postero-cervical region (C6-C7) (Fig. 3).

During autopsy, section of the above-mentioned lesions revealed the presence of 5 fragmented pellets.

A thorough forensic investigation revealed that the head had been severed from the body by means of multiple chop/incised wounds through the cervical soft tissue and the fourth cervical vertebra, in the left-to-right and anterior-to-posterior direction.

There was no evidence of haemorrhage into the tissues at the edges of the incised wounds. However, as histological examination was unable to distinguish between definitely fatal wounds and wounds inflicted after death, decapitation was defined as having occurred

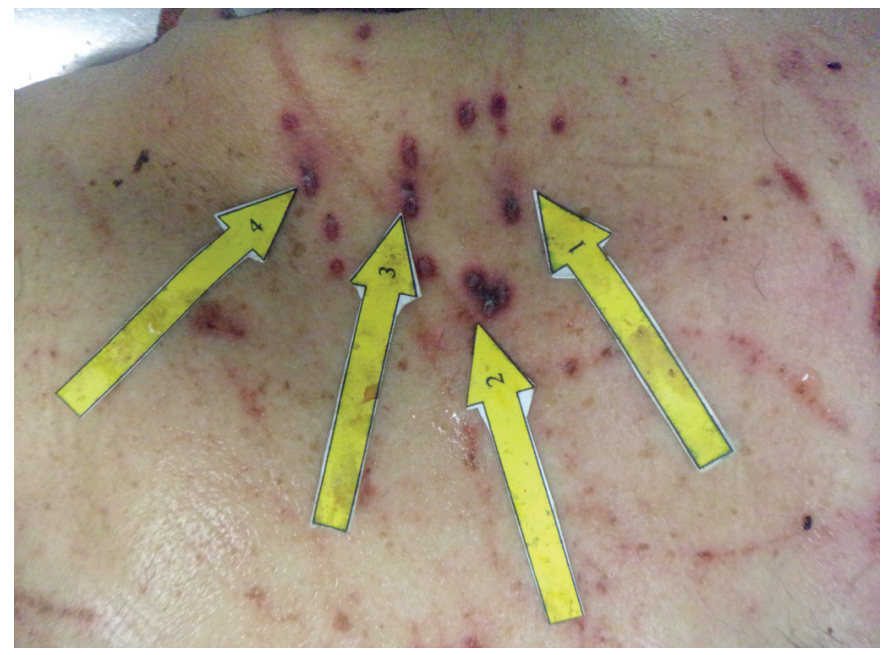

Figure 3. External examination: The upper back of the victim, showing 16 contusions and 4 entrance wounds (yellow arrows). 
in limine vitae.

Examination of the whole body revealed no other significant trauma or any natural diseases that could have caused or contributed to death. Moreover, toxicological analysis proved negative for alcohol, drugs and substances of abuse.

Death was therefore attributed to a combined mechanism: a head wound caused by a multiple projectile from a firearm, and subsequent decapitation by means of a large sharp weapon, such as a machete. This interpretation of the cause of death stemmed from the fact that, as the head was missing, it was not possible to determine whether the victim had died as a result of the gunshot alone. Likewise, it could not be determined whether the victim had been struck by both of the shots (one a single projectile, the other a multiple projectile) fired by the same weapon (a pistol), as stated by the murderer. On the basis of the autopsy evidence, it could only be ascertained that the victim had been hit by a multiple projectile, since the pattern of the pellets embedded in the back of the neck indicated indirectly that head had also been hit. Moreover, the fact that only five pellets had penetrated the back of the neck, and not in great depth, while 16 skin contusions were also present, was deemed to indicate that the presumed shot to the head had been low, and thus possibly not immediately fatal.

Subsequent police investigations revealed that the victim had been killed elsewhere and that the body had been rolled down the hill to the spot where it was found. Unfortunately, the head was never found (the murderer stated that he had thrown it into a rubbish bin, the contents of which were destined for incineration).

\section{Aggressiveness and narcissism: in-depth analysis of the case and discussion}

Narcissistic aggressiveness, which was present in the case reported, displays various features and profiles, all of which are characterized by the prevalence of destructive aspects.

As is well known, the concept of narcissism was developed by Freud, but was revitalized by the theories of Kohut and Kernberg about 50 years ago. Both of these scholars illustrated the relationships between narcissism and violence: Kohut particularly with regard to outbursts of narcissistic rage [7]; Kernberg, in greater detail, with his theorisation of the borderline organization of personality, of which narcissistic disorders constitute a subtype. In the narcissistic disorders, rage develops when the subject does not succeed in attaining his aims and objectives. Furthermore, Kernberg depicts two narcissistic situations of greater severity: malignant narcissism and antisocial personality disorder $[8,9]$, this latter describing a condition similar to that of psychopathy. The syndrome of malignant narcissism displays the co-presence of several conditions: narcissistic personality disorder, antisocial behavior, ego-syntonic aggressiveness and sadism directed towards others or the self, with suicide attempts or self-mutilation and a marked paranoid orientation. Moreover, aggressiveness and sadism combine with excitation and heightened self-esteem [10], and any provocation on the part of the victim may produce violence, against the self or others [9]. Consequently, aggressive and homicidal behaviors can be seen as motivated acts of retaliation perpetrated in the desperate attempt to regain control and to restore the sense of self-sufficient grandiosity manifested [10].

In antisocial personality disorder, which is more serious, violent criminal behaviors, ego-syntonic sadism and a paranoid orientation are present in the aggressive subtype. By contrast, the passive-parasitic subtype is characterized by the tendency to lie, by criminal behaviors that are not directly violent (prostitution, theft and fraud) and by a general inclination to passivity. Indeed, in these cases, the antisocial behavior reflects the feeling of having a right to everything, ego-syntonic greed is rationalized by the pathologically grandiose self (9), and "good" interiorized relationships are missing.

An essential characteristic of the subject who is oriented toward narcissism [10] is rage $[10,11,12]$. This phenomenon fits into a spectrum that ranges from simple anger to frank destructiveness and which, beyond other similar chronic forms, oscillates among ingratitude [11], sarcasm [12], complaining [13] and arrogance [14]. It is also linked to vindictiveness, in the sense not only of the removal of pain and of the anguish of separation [15], but also as a solution that is consciously aimed at inflicting punishment, and thereby obtaining some relief; and at the unconscious level serves both to conceal an injury suffered by the Ego in the very first years of life and relived in adult [16] and to heal the grandiosity that has been wounded by the victim $[4,5]$. It follows that the need to take revenge, to right a wrong, to wipe out an injury by any means whatsoever, and an implacable urge to pursue all these ends are features of narcissistic rage in all its forms, and distinguish it from other kinds of aggressiveness [17]. Another very important marker is hatred, in the sense of a veritable "core affect of aggressiveness" [9], in the sense that, indeed, it constitutes "a subsequent and structured aspect of rage, just as envy is a particular structured development of hatred". Indeed, if it is true that "both the ability to love and the ability to hate are innate and require activation and environmental developments" - unlike the view of aggressiveness as being secondary to the frustration of the need to be loved - then hatred is "a complex aggressive affect". Unlike the acute reactions of rage and the easily changeable cognitive aspects of anger and rage, the cognitive aspect of hatred is chronic and stable. Hatred also has roots in the character, roots which imply strong rationalization and corresponding distortions of the functions of the ego and superego. The primary aim of an individual who is consumed by hatred is to destroy the object of that 
hatred, a specific object of the unconscious imagination, and the conscious derivates of that object; at bottom, both a need and a desire are directed at the object, and its destruction is equally a need and a desire [8]. In addition, the absence or significant reduction of empathy must also be regarded as a feature of narcissistic destructiveness, as narcissistic, exhibitionist and aggressive personalities display general indifference to the fate of others $[18,19$, 20]. Indeed, this deeply-rooted lack of empathy prevents such personalities from placing themselves in the other person's shoes [21]; to them, the other person is always and only a mirror, that anthropological device which harks back to the ghost, which is the true love object of narcissistic desire [22].

From an in-depth analysis of the case described, it emerges that the profile of the murderer was that of a man who was deeply scarred by the family conflicts that took place during his childhood, by the profoundly ambivalent relationships with his parents, and by the lack of stable and precise object relations. These elements conditioned the development of modes of thought and behavior conditioned by intense feelings of inadequacy in his relationships with others. Thus, he coped with these feelings by avoiding social relationships and exercising excessive control over the environment around him.

In the background, there was also an evident fragility of identity, which was conditioned by the ambiguity that permeated the period of his development. Thus, feeling empty and "out of place", he looked for idealized figures who could provide him with apparent stability, who could enable him to maintain an acceptable self-image. This aspect clearly emerges when he talks about his sexual difficulties and relationships with women, difficulties that are overcompensated through the grandiose construction of the image of the "man of the country", who looks down on women who reject this lifestyle. Moreover, in his tendency to sadism, we see the need to utilise aggressiveness in order to control and to manage the threat of disdain and rejection, which would undermine the narration of his self-identity.

The subject's relationship with his uncle constituted a further threat to his identity. Having been a role model since the subject's boyhood, the uncle subsequently became a harsh tormentor and an intolerable obstacle to the murderer's self-esteem, in that, through his connection with the mayor, he was the bearer of the threat of expropriation of the subject's land, which was the source of his self-esteem.

With regard to the dynamics of the murder, the act described above has a paradoxical aspect: the gap between the evident horror and huge destructiveness of the crime, on the one hand, and the apparent banality of the motive, on the other. Indeed, expert investigation found that the murder was not underpinned by the presence of psychotic elements or of a criminal plan; rather, it stemmed from the sadistic pleasure of controlling and despising the other, which is typical of malignant narcissism, and was enacted with exaggerated violence.

From the criminogenic standpoint, the murder can be seen as having stemmed from the basic duality of the subject's personality - a personality marked by early suffering and narcissistic overcompensation. Thus, his violent behavior was triggered by the rancor aroused by the victim's intolerable attitude. Indeed, the victim was deemed guilty both of having humiliated the subject by unfairly and unjustifiably "freezing" their relationship, and of being the vehicle for the threat to expropriate his land, which was a symbol of his lifestyle choice and his freedom.

It was within this painful relationship that the subject's vengeance was triggered; the wrongs suffered and the uncle's unacceptable behavior fuelled his rage against the umpteenth narcissistic wound inflicted. In other words, the key to deciphering this homicide lies, in our view, in understanding the irrevocably shattered relationship between the murderer and the victim. No longer was the uncle the admirable figure who had instilled in the subject a love of nature; now, with the complicity of a man of power, he was trying to deprive the subject of a fundamental prop of his self-image: that of the woodsman, of the free man of the forest.

If we broaden our view to encompass a psychoanalytical reconstruction, the figure of the uncle could be representative of the rejection suffered at the hands of the father, whom the subject rarely mentions - a father who, on the one hand, urged his son to take on a macho identity, while, on the other, not allowing him to remain the sole proprietor of access to the mother/land (the pathway leading to the wood that he owned). The rage thus engendered was exacerbated all the more by the fact that the attack on the subject's narcissistic grandiosity had been launched by the very person (his uncle) who had acted as a surrogate for his absent father, leading him in his exploration of nature. Moreover, the act perpetrated against the uncle recalls the father's violence against the mother, as if the subject were avenging the attempted strangulation of his mother by decapitating the aggressor.

In conclusion, in cases of homicide such as this, it is clearly very important to examine the entire lives of the protagonists involved and to reconstruct their personal and family history, the broad context and the setting in which the crime originates. In the case described here, this involved reconstructing the history of the relationships among the mother, father and son, their personalities and that of the victim, and the dramatic interweaving of their respective histories before the murder took place. Only in this way can the genesis of the murder be understood within a criminological-clinical perspective. Nevertheless, care must be taken in order to ensure that the sphere of comprehensibility is kept separate from that of psychiatric-forensic evaluation [23]. 
This research did not receive any specific grant from funding agencies in the public, commercial, or notfor-profit sectors.

Conflict of interest. The authors declare that there is no conflict of interest. This work was not supported by any agency.

Consent. In this notable case there are no personal-specific medical information about an identifiable individual and the data concerning the patient have been sufficiently anonymised.

\section{References}

1. Byard RW, Gilbert JD. Characteristic features of deaths due to decapitation. Am J Forensic Med Pathol. 2004;25(2):129-30.

2. Dogan KH, Demirci S, Deniz I, Erkol Z. Decapitation and dismemberment of the corpse: A matricide case. J Forensic Sci. 2010 Mar 1;55(2):542-545.

3. Türk EE, Püschel K, Tsokos M. Features Characteristic of Homicide in Cases of Complete Decapitation. Am J Forensic Med Pathol 2004;25(1):83-86

4. Winskog C, Byard RW. Decapitation: a rare form of postmortem mutilation. Forensic Sci Med Pathol. 2016;12(1):98-100.

5. Bushman BJ, Baumeister RF. Threatened Egotism, Narcissism, Self-Esteem, and Direct and Displaced Aggression: Does Self-Love or SelfHate Lead to Violence? J Pers Soc Psychol. 1998;75(1):219-229.

6. Lambe S, Hamilton-Giachritsis C, Garner E, Walker J. The Role of Narcissism in Aggression and Violence: A Systematic Review. Trauma, Violence, Abus. 2018;19(2):209-230.

7. Kohut H. Thoughts on Narcissism and Narcissistic Rage. In: The Search for the Self. 2018.

8. Kernberg OF. Aggressivity, narcissism, and self-destructiveness in the psychotherapeutic relationship: New developments in the psychopathology and psychotherapy of severe personality disorders. 2004.

9. Allison GH. Aggression in Personality Disorders and Perversions: By Otto F. Kernberg. New Haven and London: Yale University Press. 1992. Pp. 316. Int J Psychoanal. 1994;

10. Ronningstam E. Narcissistic personality disorder: A current review. Current Psychiatry Reports. 2010;12(1):68-75.

11. Bergler E. Psicopatologia dell'ingratitudine, in: AA.VV., Le rabbie croniche, Boringhieri, Torino, 1992, pp. 13-22.

12. Slap JW. Il sarcasmo, in: AA.VV., Le rabbie croniche, Boringhieri, Torino, 1992, pp. 102-118.

13. Schmideberg M. The treatment of psychopaths and borderline patients. Am J Psychother. 1947;1(1):45-70.

14. Bion W. L'arroganza, in: AA.VV., Le rabbie croniche, Bollati Boringhieri, Torino, 1992, pp. 91-102.

15. Searles HF. La psicodinamica della vendicatività, in: AA.VV., Rabbia e vendicatività, Bollati Boringhieri, Torino, 1992, pp. 85-106.

16. Socarides CW. La vendicatività: il desiderio di "pareggiare i conti", in: AA.VV., Rabbia e vendicatività, Bollati Boringhieri, Torino, 1992, pp. 107-138.

17. Kohut H. The Analysis of the Self: A Systematic Psychoanalytic Approach to the Treatment of Narcissistic Personality Disorders, International Press, New York, 1971.

18. Jolliffe D, Farrington DP. Empathy and offending: A systematic review and meta-analysis. Aggress Violent Behav, 2004 9.5: 441-476.

19. Hepper EG, Hart CM, Sedikides C. Moving Narcissus: Can Narcissists Be Empathic? Personal Soc Psychol Bull. 2014 Sep;40(9):1079-1091.

20. Hepper EG, Hart CM, Meek R, Cisek S, Sedikides C. Narcissism and empathy in young offenders and non-offenders. Eur J Pers. 2014 28.2: 201-210.

21. Boella L. Sentire l'altro: Conoscere e praticare l'empatia, Raffaello Cortina, Milano, 2006.

22. Stanghellini G. Noi siamo un dialogo: Antropologia, psicopatologia, cura, Raffaello Cortina, Milano, 2017.

23. Ventura F, Portunato F, Pizzorno E, Mazzone S, Verde A, Rocca G. The Need for an Interdisciplinary Approach in Forensic Sciences: Perspectives from a Peculiar Case of Mummification. J Forensic Sci. 2013 May;58(3):831-836. 